ISSN 2413-0877 Volume 2 (2015) 587

The 3rd International Conference on Biological Science 2013

(The 3rd ICBS-2013)

\title{
ORCHID RE-INVENTORY IN PEGUNUNGAN MENOREH, PREFECTURE PROVINCE OF KULONPROGO, D.I. YOGYAKARTA
}

\author{
M.D. Lawrie, S.P.M. Putri, H. Pangesti, D.M. Dewi, and U. Khalsum \\ Faculty of Biology, Universitas Gadjah Mada Jalan Teknika Selatan, Sekip Utara, Bulaksumur, Sleman, D.I. \\ Yogyakarta 55281 \\ e-mail : biosc.biogama@gmail.com
}

\begin{abstract}
Pegunungan Menoreh is one area with high orchid diversity. In this area, have a suitable climate for growing orchids. The last research was conducted by Nugroho et al. (2010) in Pegunungan Menoreh that found 11 species orchid. However, it was still potentially to found more orchid. This research has been carried out on May 2011- November 2012 after last inventory on 2010. The aim of this research is to complete the basic data of orchid diversity in Pegunungan Menoreh, Kulonprogo, D.I. Yogyakarta. This research was done by explorative method in Baladewa, Bukit Krengseng, Ngasinan and Watublencong. The results showed 19 orchid species from 17 genera consists of 6 terrestrial species, 2 saprophyte species, 10 epiphytic species and 1 amoebophyte species. The terrestrial species were Arundina graminifolia (D. Don) Hochr., Dienia ophrydis(J. König) Seidenf., Malaxis sp., Nervilia aragoana Commons ex Gaudich., Spathoglottis plicata Blume and Vanilla planifolia Jacks. Ex Andrews. The saprophyte species were Didymoplexis pallens Griff. and Epipogium roseum(D. Don) Lindl. The epiphyte species were Acriopsis lilifolia (Koenig) Ormerod, Appendicula ramosa Blume.,Cymbidium sp., Dendrobium mutabile Blume (Lindl.), D. crumenatum Swartz, Eria retusa (Blume) Rchb.f., E.Javanica (Sw.) Blume, Flickingeria fimbriata(Blume) A.D. Hawkes, Liparis condylobulbon Rchb.f. and Oberonia sp. The amoebophytes was Zeuxine gracillis.
\end{abstract}

Key words : orchid diversity, Pegunungan Menoreh, re-inventory

ISSN 2413-0877 (C) 2015 The Authors.

Published by KnowledgeE Publishing Services This is an open access article under the CC BY-NC-ND license (http://creativecommons.org/licenses/by-nc-nd/4.0)

Selection and Peer-review under responsibility of the 3rd ICBS-2013

Doi http://dx.doi.org/10.18502/kls.v2i1.222 